\title{
Echokardiografie v diagnostice akutního srdečního selhání
}

\section{Radek Pudil}

\section{I. interní kardioangiologická klinika LF UK a FN, Hradec Králové}

Efektivní a včasná diagnostika akutního srdečního selhání je doposud výzvou v urgentní medicíně. Základním cílem diagnostického procesu není pouze diferenciální diagnostika dušnosti a potvrzení diagnózy srdečního selhání, ale současně určení tíže selhání, jeho etiologie a vyloučení mechanických komplikací. Tento proces je nutné provést velmi rychle, zpravidla po iniciálním zajištění pacienta (velmi často v prostorách urgentních př́imů). Důvodem je diagnostika př́ičin a zhodnocení tíže srdečního selhání, pro které je nutné pacienta transportovat do kardiocentra k další léčbě.

Důvodem urychleného a zajištěného transportu do kardiocentra jsou: akutní koronární syndromy, mechanické komplikace, ke kterým patří např. ruptura papilárního svalu, mezikomorového septa, dále patologie chlopenních náhrad (porucha funkce nativních či implantovaných chlopní v důsledku endokarditidy či trombózy), disekce aorty a řada dalších. Ve všech prípadech jde o čas a transport pacienta do kardiocentra vybaveného možností revaskularizace či kardiochirurgického výkonu je nezbytný.

Základem diagnostického procesu zůstává i nadále analýza anamnestických údajů (pokud jsou dostupné), fyzikální vyšetření, elektrokardiogram, laboratorní vyšetření a zobrazovací metody, mezi které patří svojí dostupností především echokardiografie. Navíc, s ohledem na zrychlení diagnostického procesu a především nutnost včasného terapeutického zásahu, se dostává do popredí užití ultrazvukových metod pro vyšetření srdce již v prostředí emergency (1). $\checkmark$ posledních letech byly vyvinuty některé protokoly pro vyšetření srdce a plic, které standardi- zují způsob vyšetření tak, aby byl realizovatelný v běžné praxi lékařem sloužícím v urgentním provozu. Patří mezi ně protokoly pro echokardiografické vyšetření srdce a plic.

Mezi standardizované protokoly pro vyšetření srdce patří tzv. FATE protocol (Focus-Assessed Thransthoracic Echocardiography) (2, 3). FATE protokol patří mezi nejrozšířenější a byl vyvinut pro lékaře urgentních provozůa intenzivisty. Zahrnuje vyšetření ze čtyř základních projekcí: subkostální čtyřdutinová, apikální čtyřdutinová, parasternální dlouhá/krátká osa, kterou doplňuje pleurální scaning (4, 5). Tř̀i doplňující projekce zahrnují: subko- stální projekci (zobrazení vena cava), apikální dvouresp. tří- a pětidutinovou projekci, které doplňuje parasternální projekce v krátké ose v rovině mitrální chlopně a v rovině báze srdeční. Cílem vyšetření je detekce základních patologických morfologických obrazů (vyloučení tamponády, př́tomnost srdeční vady, mechanické komplikace), posouzení velikostí jednotlivých srdečních oddílů, zhodnocení tlouštky stěny srdeční, posouzení funkce obou komor, posouzení obsahu pleurálních dutin. Z doplňujících projekcí je možné získat údaje o stavu volemie, tlaku v plicnici/plnícího tlaku levé komory, orientační posouzení poruch kinetiky. V některých

Obr. 1. Postavení zobrazovacích metod v diagnostickém algoritmu akutního srdečního selhání upraveno podle (1); pozn. angiografie, resp. koronarografie jen v prípadě podezření na akutní koronárni syndrom, CT vyšetření prí podezreneni na plicni embolii nebo disekci aorty, v prípadě nedostatečné kvality zobrazení při kompletnípodrobnéechokardiografii lze využit magnetickou rezonanci, vyšsetrenípred nebo po dimisi s cilem nalézt príčinu srdečního selhání

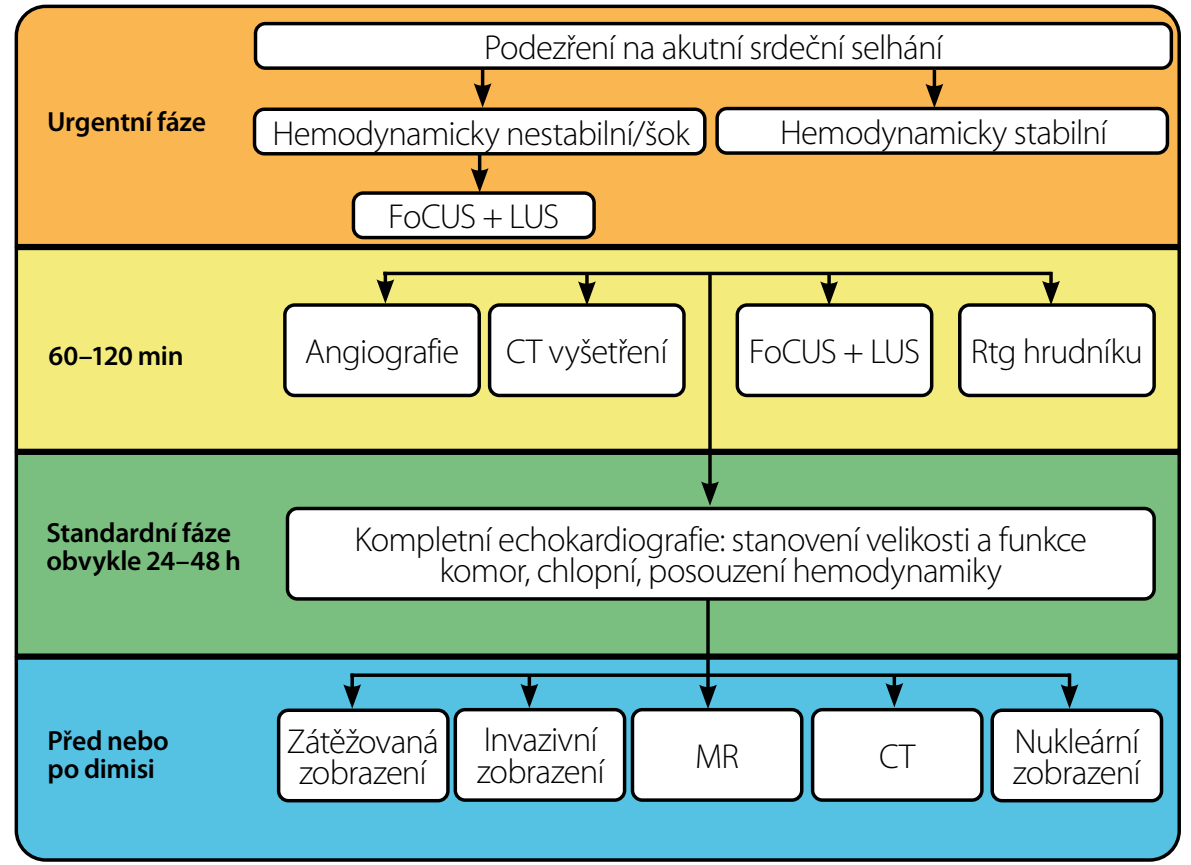

KORESPONDENČNÍ ADRESA AUTORA:

prof. MUDr. Radek Pudil, Ph.D., pudilradek@yahoo.com

I. interní kardioangiologická klinika LF UK a FN, Sokolská 581, 50005 Hradec Králové
Cit. zkr: Interv Akut Kardiol 2020; 19(4): 201-202

Článek prijiat redakcí: 12. 10. 2020

Článek príijat k publikaci: 13. 10. 2020 


\section{EDITORIAL}

prípadech je na místě provedení ultrazvukového vyšetření plicní tkáně tzv . „Lung UltraSound“ (LUS), který pomůže v diagnostice edému plic, tekutiny v pleurální dutině a diferenciální diagnostice ostatních prírčin dušnosti (6). Není třeba zdưrazňovat, že je nutné umět výsledky těchto vyšetření správně interpretovat v důsledku vlivu akutního stavu na řadu echokardiografických parametrů (krevní tlak, volemie, mechanická ventilace apod.).

Na tento stav reagovala doporučení odborných společností. V únoru letošního roku bylo publikováno doporučení Asociace srdečního selhání Evropské kardiologické společnosti (1). Tento dokument zasazuje roli echokardiografie nejenom do diagnostického schématu akutního srdečního selhání, ale určuje časový rámec pro provedení echokardiografického vyšetření (obr. 1), kdy základní protokol (FOCUS/FATE protokol) prrípadně LUS by měly být u hemodynamicky nestabilních pacientů provedeny inned, tedy ještě v prostředí emergency nebo velmi časně na jednotce intenzivní péče. U hemodynamicky stabilních pacientů je doporučeno, aby tato vyšetření byla provedena do 60-120 minut od prijietí. Podrobné a úplné echokardiografické vyšetření s podrobným posouzením velikosti a funkce srdečních oddílů, chlopenních vad a podrobným posouzením hemodynamicky je doporučeno provést v intervalu do 24-48 hodin.

To vše znamená pokrok $v$ diagnostice a stratifikaci nemocných s akutním srdečním selháním, ale prínáší s sebou také několik dalších otázek. Patří mezi ně:

\section{LITERATURA}

1. Celutkiene J, Lainscak M, Anderson L, et al. Imaging in patients with suspected acute heart failure: timeline approach position statement on behalf of the Heart Failure Association of the European Society of Cardiology. Eur J Heart Fail 2020; 22(2): 181-195.

2. Jensen MB, Sloth E, Larsen KM, Schmidt MB. Transthoracic echocardiography for cardiopulmonary monitoring in intensive care. Eur J Anaesthesiol 2004; 21(9): 700-707.

3. Ohman J, Harjola VP, Karjalainen P, Lassus J. Focused echocardiography and lung ultrasound protocol for gui-
- znalost obou protokolů a především schopnost interpretovat jejich výsledky personálem zajištujícím služby urgentních oddělení, - zajištění dostupnosti těchto služeb v režimu 7/24 (nejenom kardiologové),

- zajištění výuky/výcviku v těchto metodikách.

Řešení těchto otázek je potřeba věnovat náležitou pozornost. V kardiocentrech dochází k rozšírení znalostí echokardiografie či prímo FATE protokolu mezi sloužícím personálem na emergencích, podobně je zajištěna 24hodinová dostupnost kardiologa se znalostí echokardiografie nebo je přímo zajištěna echokardiografická príslužba.

Avšak podstatné je řešit rozdíl mezi kardiocentry a ostatními zdravotnickými zařízeními, která zajištujuí nepřetržitou službu mimo kardiocentra (např. urgentní oddělení okresních nemocnic). Tato oddělení mají kličovou roli ze dvou zásadních důvodů: (1) jsou místem, kde je primárně ošetřeno a diagnostikováno velké množství pacientů přicházejících s dušností a přiznaky akutního srdečního selhání, (2) jsou místem, kde včasný transport do kardiocentra může velmi významně ovlivnit prognózu nemocného (např. akutní koronární syndromy, šokové stavy s nutností mechanické srdeční podpory, mechanické komplikace vedoucí ke vzniku akutního srdečního selhání apod.). Tento přístup má potenciál snízit mortalitu nemocných s akutním srdečním selháním.

Pro zajištění tohoto přístupu je nezbytné rozšiření znalostí základních echokardiografických protokolů u personálu (velmi často tzv.

ding treatment in acute heart failure. ESC Heart Fail 2018; 5(1): 120-128.

4. Holm JH, Frederiksen CA, Juhl-Olsen P, Sloth E. Perioperative use of focus assessed transthoracic echocardiography (FATE). Anesth Analg 2012; 115(5): 1029-1032.

5. Nagre AS. Focus-assessed transthoracic echocardiography: Implications in perioperative and intensive care. Ann Card Anaesth 2019; 22(3): 302-308.

6. Lichtenstein DA, Meziere GA. Relevance of lung ultrasound in the diagnosis of acute respiratory failure: the BLUE proto- "nekardiologư") zajištujujicího tyto služby i mimo kardiocentra. V této oblasti se významně angažují jak kardiologicky zaměřené odborné společnosti, tak společnosti zabývající se intenzívní medicínou na evropské i národní úrovni. Např. Evropean Association of CardioVascular Imaging (EACVI), která vydala doporučení pro výuku a vzdělávání lékař̆u v této oblasti (7). Podobně European Society of Intensive Care Medicine (ESICM), která připravila program European Diploma in advanced critical care EchoCardiography (link: https://www.esicm. org/education/edec-2/. Existují také doporučení pro použití malých echokardiografických přistrojů (handheld ultrasound devices) (8). Velmi kladně Ize hodnotit snahy České kardiologické společnosti a České společnosti anesteziologie, resuscitace a intenzivní medicíny (ČSARIM), která pořádá kurzy a také se podílí na tvorbě vzdělávacích standardů pro echokardiografii v intenzivní péči (EDEC). Součástí aktivity ČSARIM je také jednání o přidělení pojištovenských kódů pro vykazování této péče v intenzivní medicíně. S potěšením Ize konstatovat, že řada lékařu i menších (např. okresních) nemocnic má zájem o tyto kurzy. Domnívám se, že je třeba tuto otázku správně uchopit a zajistit rozšíření tohoto postupu do širší nekardiologické veřejnosti. K tomu musí napomoci také systém vzdělávání nejenom $\checkmark$ kardiologii a intenzivní péči, ale také například $\checkmark$ interní medicíně.

Článek byl podpořen prostředky výzkumného projektu Progres Q40/3.

col. Chest 2008; 134(1): 117-125.

7. Neskovic AN, Skinner H, Price S, et al. Reviewers: This document was reviewed by members of the ESDC. Focus cardiac ultrasound core curriculum and core syllabus of the European Association of Cardiovascular Imaging. Eur Heart J Cardiovasc Imaging 2018; 19(5): 475-481.

8. Cardim N, Dalen H, Voigt JU, et al. The use of handheld ultrasound devices: a position statement of the European Association of Cardiovascular Imaging (2018 update). Eur Heart J Cardiovasc Imaging 2019; 20(3): 245-252. 